\title{
PENYULUHAN DAN PELATIHAN DENGUE PADA IBU SERTA DETEKSI DINI INFEKSI DENGUE PADA PASIEN DENGAN SUSPEK INFEKSI DENGUE DI TULUNGAGUNG, JAWA TIMUR
}

\section{(DENGUE COUNSELING AND TRAINING FOR MOTHERS, AND EARLY DETECTION OF DENGUE INFECTION FOR PATIENTS WITH DENGUE INFECTION SUSPENSION IN TULUNGAGUNG, EAST JAVA)}

\author{
Juniastuti $^{1,2}$, Lynda Rossyanti ${ }^{1,3}$, Manik R. Wahyunitisari ${ }^{1,2}$, Achmad Ardianto ${ }^{4}$, \\ Rebekah J. Setiabudi ${ }^{1,2}$, Suhintam Pusarawati ${ }^{1,3}$, Dewi Setyowati ${ }^{1}$, Putri S. \\ Wulandari ${ }^{1}$ \\ ${ }^{1}$ Program Magister Ilmu Kedokteran Tropis, ${ }^{2}$ Departemen Mikrobiologi, \\ ${ }^{3}$ Departemen Parasitologi, Fakultas Kedokteran, Universitas Airlangga; ${ }^{4}$ Puskesmas \\ Karangrejo, Tulungagung \\ e-mail: juniastutisyafik@yahoo.com
}

\begin{abstract}
Tulungagung Regency in East Java, is a Dengue endemic area, but the movement of 1 house 1 jumantik / larva monitor (Government program for controlling Dengue vectors), which involves every family in the inspection, monitoring and eradication of mosquito larvae, has not yet been implemented. The objectives of this community service activity are 1) increasing maternal knowledge about Dengue, 2) increasing maternal efforts in eradicating Aedes mosquito larvae (Dengue vectors) and 3) improving mother's skills in monitoring mosquito larvae in Karangrejo District; and 4) determine the proportion of early dengue infection at the Karangrejo Health Center. The method used is counseling, training and laboratory examinations (rapid test with the NS1 Dengue kit). This community service obtained the conclusion of counseling can increase the knowledge of dengue in mothers, counseling can increase maternal efforts in eradicating mosquito larvae, training to improve the skills of mothers in monitoring mosquito larvae, there are $10.8 \%$ of patients with symptoms of dengue infection who show positive NS1.
\end{abstract}

Keywords: ABJ, aedes mosquito, dengue, larvae monitoring

\begin{abstract}
abstrak
Kabupaten Tulungagung di Jawa Timur, merupakan daerah endemis Dengue, namun gerakan 1 rumah 1 jumantik/juru pemantau jentik (program Pemerintah untuk pengendalian vektor Dengue) yaitu yang melibatkan setiap keluarga dalam pemeriksaan, pemantauan, dan pemberantasan jentik nyamuk, masih belum banyak diterapkan. Tujuan kegiatan pengabdian masyarakat ini adalah 1) meningkatkan pengetahuan ibu tentang Dengue, 2) meningkatkan upaya ibu dalam memberantas tempat perindukan jentik nyamuk Aedes (vektor Dengue) dan 3) meningkatkan ketrampilan ibu dalam memantau jentik nyamuk di Kecamatan Karangrejo; serta 4) menentukan proporsi kejadian infeksi Dengue secara dini di Puskesmas Karangrejo. Metode yang digunakan adalah penyuluhan, pelatihan dan pemeriksaan laboratorium (uji cepat dengan kit NS1 Dengue). Pengmas ini memperoleh simpulan penyuluhan dapat meningkatkan pengetahuan dengue pada ibu, penyuluhan dapat meningkatkan upaya ibu dalam memberantas tempat perindukan jentik nyamuk, pelatihan meningkatkan ketrampilan ibu dalam memantau jentik nyamuk, ada 10,8\% pasien dengan gejala infeksi Dengue yang menunjukkan NS1 positif.
\end{abstract}

Kata kunci : ABJ, Dengue, nyamuk Aedes, pemantauan jentik 


\section{PENDAHULUAN}

Kasus demam berdarah dengue (DBD) merupakan masalah kesehatan yang penting di Jawa Timur. Pada tahun 2016, Jawa Timur menduduki peringkat kedua terbanyak untuk jumlah kasus DBD (setelah Jawa Barat) dan peringkat pertama terbanyak untuk jumlah kasus DBD yang meninggal (Pusdatin Kemenkes RI, 2017). Data Dinas Kesehatan Jawa Timur pada tahun 2015 menunjukkan di Tulungagung, jumlah kasus DBD sebanyak 919 dengan CFR (Case Fatality Rate) paling tinggi $(48,1 \%)$ di tingkat provinsi. Program kesehatan untuk menurunkan angka kesakitan dan kematian DBD di Tulungagung sangat mendesak untuk segera dilakukan. Pencegahan penyakit DBD yang selama ini digalakkan secara nasional oleh Pemerintah adalah Gerakan 3M/Gerakan 3M Plus yaitu menguras, menutup, mengubur serta melakukan segala bentuk pencegahan lainnya aantara lain memberi bubuk larvasida pada tempat air yang sulit dibersihkan, menggunakan kelambu saat tidur, menggunakan anti nyamuk/repellent, memelihara ikan pemangsa jentik nyamuk. Namun, penyakit DBD masih selalu terjadi tiap tahun (terutama saat musim hujan), karena masyarakat sering tidak peduli dan tidak menjalankan gerakan $3 \mathrm{M}$ Plus secara teratur dan berkesinambungan, hal ini juga dijumpai di wilayah Kabupaten Tulungagung.

Masyarakat tidak menyadari bahwa di dalam/luar rumahnya terpelihara nyamuk Aedes sp. (Aedes aegypti dan Aedes albopictus) yang merupakan vektor/penular penyakit DBD. Untuk meningkatkan implementasi program 3M Plus, Pemerintah mencanangkan program "Gerakan 1 Rumah 1 Jumantik (juru pemantau jentik)", yaitu melibatkan setiap keluarga dalam pemeriksaan, pemantauan, dan pemberantasan jentik nyamuk (Pusdatin Kemenkes RI, 2016). Ibu rumah tangga paling berperan penting dalam pendidikan keluarga dan sebagai manajer utama keluarga, karena itu penyuluhan tentang Dengue dan pelatihan pemantauan jentik nyamuk Aedes yang ditujukan kepada ibu rumah tangga merupakan langkah penting dalam pencegahan penyakit DBD. Selain itu, deteksi dini infeksi Dengue menggunakan uji cepat (uji laboratorium) sangat penting dalam menurunkan angka CFR yang sangat tinggi di Kabupaten Tulungagung ini.

Pada kegiatan pengabdian masyarakat ini, akan dilakukan upaya penyuluhan tentang Dengue dan pelatihan juru pemantau jentik nyamuk pada ibu rumah tangga di wilayah Puskesmas Karangrejo, Kabupaten Tulungagung. Gerakan 1 Rumah 1 Jumantik masih diterapkan di 1 Desa di wilayah tersebut. Uji cepat untuk mendeteksi antigen (NS1) virus Dengue juga sangat penting dalam deteksi dini infeksi Dengue, ditujukan pada pasien dengan gejala infeksi Dengue yang berobat ke puskesmas. Tujuan kegiatan ini adalah meningkatkan pengetahuan ibu tentang Dengue dan upaya ibu dalam memberantas tempat perindukan jentik nyamuk (sebagai upaya pencegahan), meningkatkan ketrampilan ibu dalam memantau jentik nyamuk, serta menentukan proporsi kejadian infeksi Dengue secara dini. Diharapkan kegiatan pengabdian masyarakat ini berkontribusi dalam menurunkan angka kesakitan dan kematian (CFR) karena infeksi Dengue di Kabupaten Tulungagung.

\section{METODE PENGABDIAN MASYARAKAT}

Kegiatan pengabdian masyarakat berupa penyuluhan dan pelatihan ditujukan pada ibu di wilayah kerja Puskesmas Karangrejo, Tulungagung serta pemberian kit uji cepat 
deteksi NS1 Dengue pada pihak Puskesmas Karangrejo untuk penentuan infeksi Dengue secara dini. Selain kegiatan penyuluhan dan pelatihan, juga dilakukan survei memantau jentik nyamuk oleh tim pengmas. Satu bulan setelah pelatihan, tim pengmas berkunjung lagi ke tempat tersebut untuk melakukan survei jentik nyamuk lagi.

Rincian penyuluhan dan pelatihan sebagai berikut : a) pemberian materi tentang Dengue (meliputi gambaran penyakit, penyebab, gejala, pengobatan secara umum dan upaya pencegahan termasuk memberantas tempat perindukan jentik nyamuk) dengan alat bantu audiovisual, b) pelatihan memantau jentik nyamuk Aedes dengan alat bantu audiovisual serta contoh jentik nyamuk Aedes yang telah diawetkan, c) tanya jawab/diskusi. Selain itu, juga diberikan buku saku ber ISBN tentang Dengue yang telah disusun oleh tim pengmas kepada peserta penyuluhan. Sedangkan kit uji cepat deteksi NS1 Dengue akan diberikan kepada pihak Puskesmas untuk deteksi dini infeksi Dengue pada pasien yang berobat ke Puskesmas Karangrejo dengan gejala infeksi Dengue, yang meliputi : demam minimal 3 hari, disertai minimal 2 gejala yaitu sakit kepala, nyeri otot, nyeri sendi, rash, perdarahan, muntah/nyeri perut (WHO, 2011).

Analisis data meliputi : 1) Tingkat pengetahuan ibu tentang Dengue, yang diukur berdasar nilai pre test dan post test, sebagai penilaian keberhasilan kegiatan penyuluhan. Klasifikasi tingkat pengetahuan sebagai berikut : baik, jika persentase jawaban benar $\geq 70 \%$; cukup, jika persentase jawaban benar 40\%-69\%; kurang, jika persentase jawaban benar $<40 \%$ (skala data : interval); 2) Ketrampilan ibu rumah tangga dalam memantau jentik nyamuk Aedes yang diukur dari kartu pemantau jentik yang diberikan. Kartu tersebut diisi dengan keberadaan jentik nyamuk di rumah tiap ibu setiap minggu selama 4 minggu setelah pelatihan. Hasil isian dimonitor oleh petugas puskesmas. Data yang diperoleh dianalisis secara deskriptif. Selain itu, tim pengmas juga melakukan pemantauan jentik nyamuk sebelum dan setelah pelatihan, untuk mengkonfirmasi data yang diperoleh para ibu. Jentik nyamuk yang diperoleh tim pengmas, diperiksa dengan mikroskop untuk identifikasi speciesnya. Data dianalisis untuk memperoleh Angka Bebas Jentik (ABJ), juga house index (HI) dan container index (CI), dengan rumus berikut : $\mathrm{ABJ}=$ jumlah rumah yang bebas jentik/jumlah rumah yang diperiksa $\mathrm{x} 100 \%$. $\mathrm{HI}=100 \%-\mathrm{ABJ} . \mathrm{CI}=$ jumlah wadah positif jentik/jumlah wadah yang diperiksa $\mathrm{x}$ 100\% (WHO, 2011); 3) Hasil uji deteksi dini infeksi Dengue, yang dianalisis secara deskriptif.

\section{HASIL DAN PEMBAHASAN}

Kegiatan pengabdian masyarakat berupa penyuluhan Dengue serta pelatihan pemantauan jentik nyamuk Aedes diberikan pada ibu di kantor kepala Desa Sukowidodo, Kecamatan Karangrejo, Kabupaten Tulungagung. Jumlah seluruh ibu yang menghadiri kegiatan tersebut sebanyak 62 orang, semuanya adalah penduduk Desa Sukowidodo.

Kecamatan Karangrejo terdiri dari 7 Desa yaitu: Desa Bungur, Desa Babadan, Desa Sukowiyono, Desa Sukowidodo, Desa Tanjungsari, Desa Sembon dan Desa Karangrejo. Jumlah penduduk di kecamatan tersebut sebanyak 23.233 orang, terdiri dari 11.754 lakilaki dan 11.479 perempuan. Kebanyakan mata pencaharian penduduk adalah petani $(52,6 \%)$, diikuti buruh $(23,4 \%)$, PNS $(14,3 \%)$, pedagang $(10,8 \%)$, pengrajin $(2,4 \%)$ dan ABRI (2,01\%). Sarana pendidikan meliputi MAN (1 sekolah), SLTP/MTS (4 sekolah), 
SD/MI (24 sekolah) dan TK (16 sekolah), dengan jumlah murid terbanyak adalah murid TK (987 anak), diikuti SLTP/MTS (776 anak), SD/MI (428 anak), dan MAN (47 anak). Jumlah anak yang tidak melanjutkan pendidikan (dari SD s.d SMA) sebanyak 27.356 anak. Prasarana kesehatan yang tersedia meliputi 1 Puskesmas (Puskesmas Karangrejo), 1 Pustu, 6 Polindes/ Ponkesdes, 25 Posyandu (UPTD Puskesmas Karangerjo, 2017). Pelayanan kesehatan yang disediakan oleh Puskesmas Karangrejo meliputi: 1) upaya kesehatan masyarakat (UKM) a.l. pelayanan promosi kesehatan dan lingkungan serta pencegahan pengendalian penyakit, 2) upaya kesehatan perorangan (UKP) a.l. pelayanan medis rawat jalan dan rawat inap serta pelayanan laboratorium, termasuk untuk pelayanan pasien dengan suspek infeksi Dengue (UPTD Puskesmas Karangrejo, 2017).

\section{Penyuluhan Dengue dan Pelatihan Memantau Jentik Nyamuk}

Penyuluhan tentang Dengue dan pelatihan memantau jentik nyamuk diberikan selama 2 hari (28-29 September 2018) pada ibu di Desa Sukowidodo, Kecamatan Karangrejo. Pada hari ke-1, diikuti sebanyak 31 orang, dan pada hari ke-2 diikuti oleh 31 orang (peserta yang berbeda dengan peserta hari ke-1). Desa tersebut dipilih, karena penduduknya belum mendapat penyuluhan tentang Gerakan 1 Rumah 1 Jumantik dari pihak Puskesmas. Kegiatan penyuluhan berjalan dengan baik, dengan respon ibu yang baik, dan beberapa ibu mengajukan pertanyaan.

Jumlah ibu yang mengikuti pre test sebanyak 28 (dari 31) pada hari ke-1 dan 30 (dari 31) pada hari ke-2. Yang tidak mengikuti pre test - post test lengkap, tidak dianalisis. Nilai pre test ibu yang mengikuti penyuluhan berkisar antara 16,67 - 83,33 dengan rerata 59,05 sedangkan nilai post test berkisar antara 33,33 - 100 dengan rerata 84,03. Hasil analisis tingkat pengetahuan pre test dan post test ditunjukkan Gambar 1. Hasil pre test menunjukkan, kebanyakan ibu memiliki tingkat pengetahuan cukup $(65,5 \%)$, sedangkan hasil post test menunjukkan kebanyakan ibu dengan tingkat pengetahuan baik (82,8\%). Hasil analisis statistik menunjukkan ada perbedaan bermakna pada tingkat pengetahuan antara sebelum (pre test) dan sesudah (post test) penyuluhan $(\mathrm{p}=0,000 ; \mathrm{p}<0,05)$. Secara umum, kemampuan ibu dalam menyerap informasi sangat baik, hanya 2 orang ibu yang masih tetap menunjukkan tingkat pengetahuan kurang setelah diberi penyuluhan. Tingkat pendidikan ibu berperan dalam kemampuan ibu menyerap materi penyuluhan.
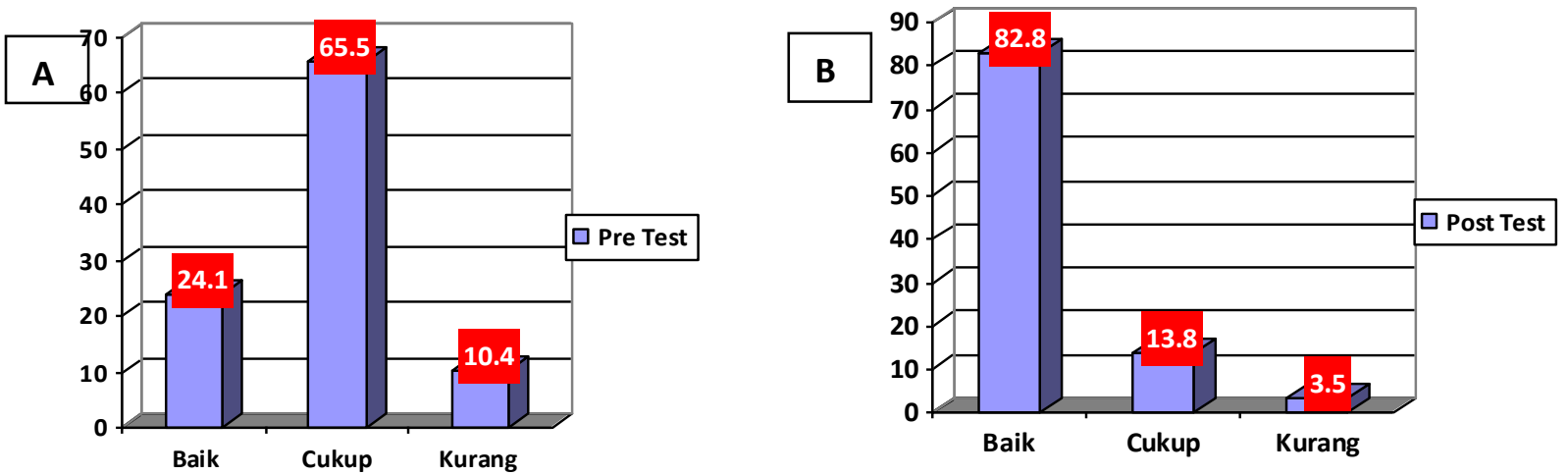

Gambar 1. Distribusi persentase tingkat pengetahuan ibu dari hasil pre test (A) dan post test (B). (Keterangan : angka dalam kotak merah adalah angka dalam persentase) 


\section{Survei Jentik Nyamuk}

Saat kunjungan pertama, tim pengmas melakukan survei jentik nyamuk Aedes (sebelum pelatihan memantau jentik nyamuk). Dari 33 rumah yang disurvei di Desa Sukowidodo, ada 8 rumah dengan jentik nyamuk Aedes aegypti (telah diidentifikasi secara mikroskopis); sehingga diperoleh house index (HI) sebesar 24,2\% dan ABJ sebesar 75,8\%. Dari 8 rumah yang ditemukan jentik nyamuk Aedes aegypti, ada 10 tempat perindukan yang diidentifikasi, kebanyakan $(7 / 10,70 \%)$ adalah bak mandi, diikuti bak wc $(2 / 10,20 \%)$ dan perangkap semut $(1 / 10,10 \%)$. Container index (CI) sebesar 13,6\% (12/88). Pada akhir minggu keempat pelatihan, dilakukan survei jentik nyamuk lagi pada daerah yang sama. Hasil survei tersebut menunjukkan ada peningkatan ABJ menjadi 82,6\%, dengan HI 17,4\%. Dari 23 rumah yang disurvei, ada 4 dengan jentik nyamuk Aedes aegypti (telah diidentifikasi secara mikroskopis). Walaupun belum memenuhi target (ABJ>95\%) (Pusdasure, 2010), namun telah menunjukkan upaya ibu yang baik dalam memberantas tempat perindukan jentik nyamuk setelah pelatihan. Perlu ditingkatkan upaya tersebut secara terus menerus, baik upaya memberantas tempat perindukan jentik nyamuk maupun memantau jentik nyamuk secara rutin. Dari 4 rumah yang ditemukan jentik nyamuk Aedes aegypti, ada 5 tempat perindukan yang diidentifikasi, terdiri dari bak mandi $(3 / 5,60 \%)$ dan diikuti bak wc $(2 / 5,40 \%)$. Bak mandi dan bak WC merupakan tempat perindukan jentik nyamuk tersering yang ditemukan. Container index $(12 \%, 5 / 42)$ sudah menurun dibanding sebelum pelatihan, walaupun belum efektif (CI>5.1\%) (Luo dkk., 2015).

Sedangkan dari hasil pemantauan jentik yang dilakukan para ibu menunjukkan pada minggu I ABJ sebesar 72,4\% dan minggu terakhir ABJ sebesar 80,6\%. ABJ yang diperoleh para ibu pada minggu I dan minggu IV sedikit lebih rendah $(2,0 \%-3,4 \%)$ dibandingkan $\mathrm{ABJ}$ yang diperoleh tim pengmas. Para ibu telah mampu memantau jentik nyamuk. Dari 62 ibu yang mengikuti pelatihan, hanya 39 orang yang mengumpulkan lembar pemeriksaan jentik nyamuk. Dari hasil pemantauan tersebut, 2 tidak dianalis karena mencantumkan saluran got yang bukan merupakan tempat perindukan jentik Aedes, sehingga total yang dianalisis ada 37 rumah. Fluktuasi ABJ semakin meningkat dari minggu I s.d minggu III, namun menurun pada minggu IV (Gambar 2). Selama 4 minggu, ABJ rumah ibu berkisar 72,4-87,9\% dengan rerata $81,3 \%$.

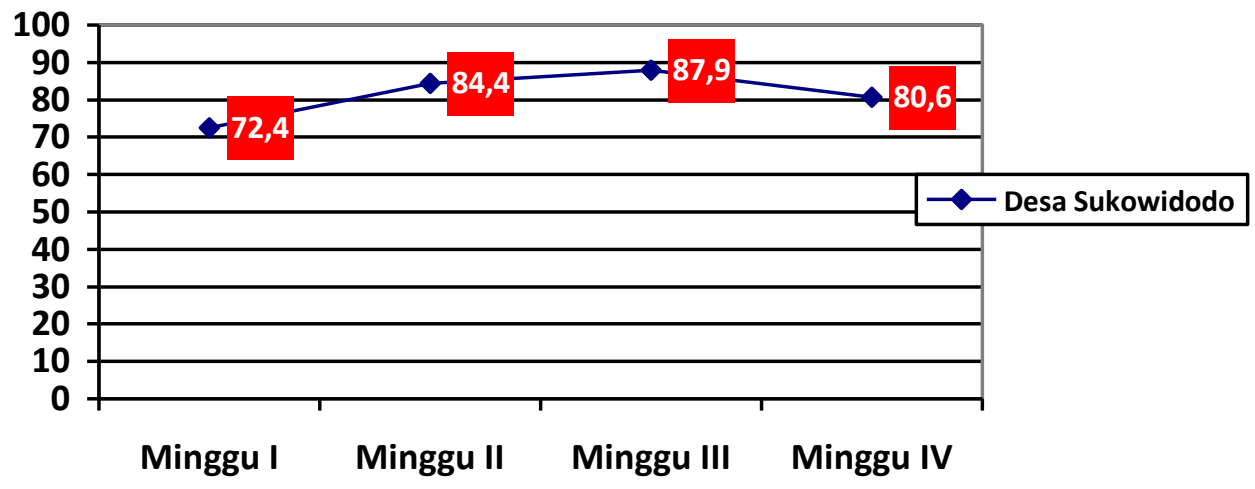

Gambar 2. Distribusi persentase ABJ rumah ibu selama minggu I-IV. 
Tabel 1. Keberadaan jentik nyamuk di lingkungan rumah ibu selama minggu I-IV

\begin{tabular}{|c|c|c|c|c|}
\hline \multicolumn{4}{|c|}{ Keberadaan jentik nyamuk } & \multirow{2}{*}{$\begin{array}{c}\text { Jumlah (persentase) } \\
\text { rumah }\end{array}$} \\
\hline Minggu I & Minggu II & Minggu III & Minggu IV & \\
\hline \multicolumn{5}{|c|}{ Tidak ada perubahan } \\
\hline+ & + & + & + & $3(8,1)$ \\
\hline- & - & - & - & $28(75,7)$ \\
\hline \multicolumn{5}{|c|}{ Menunjukkan penurunan jentik nyamuk positif } \\
\hline+ & - & - & - & $3(8,1)$ \\
\hline \multicolumn{5}{|c|}{ Jentik nyamuk ditemukan lagi } \\
\hline+ & + & - & + & $2(5,4)$ \\
\hline- & - & + & + & $1(2,7)$ \\
\hline Total & & & & 37 (100) \\
\hline
\end{tabular}

Sebanyak $8,1 \%$ rumah menunjukkan keberadaan jentik nyamuk tetap positif selama minggu I-IV, dan $75,7 \%$ rumah tetap menunjukkan jentik nyamuk negatif. Sebanyak total $8,1 \%$ rumah yang menunjukkan perubahan dari jentik nyamuk positif menjadi negatif sejak minggu II. Sebanyak $8,1 \%$ rumah lainnya menunjukkan keberadaan jentik nyamuk positif lagi setelah sebelumnya sempat negatif (Tabel 1). Peran ibu dalam memberantas tempat perindukan jentik nyamuk secara rutin perlu ditingkatkan.

\section{Uji Cara Cepat Deteksi Infeksi Dengue (NS1)}

Dari pemeriksaan NS1 pada 37 pasien dengan gejala infeksi Dengue, $4(10,8 \%)$ di antaranya menunjukkan hasil positif. Uji yang tersedia di Puskesmas Karangrejo adalah uji IgM/IgG, yang mana uji ini tidak dapat mendeteksi secara dini infeksi Dengue. Data hasil uji NS1 ini penting diinformasikan pada pemangku kebijakan kesehatan di daerah tersebut, agar dapat dilakukan tindakan pencegahan penularan pada masyarakat dengan baik.

\section{PENUTUP}

\section{Simpulan}

Capaian kegiatan pengabdian masyarakat di wilayah Puskesmas Karangrejo, Kabupaten Tulungagung: Penyuluhan dapat meningkatkan pengetahuan Dengue pada ibu, penyuluhan dapat meningkatkan upaya ibu dalam memberantas tempat perindukan jentik nyamuk, pelatihan dapat meningkatkan ketrampilan ibu dalam memantau jentik nyamuk, sebanyak 10,8\% pasien dengan gejala infeksi Dengue menunjukkan NS1 positif.

\section{Saran}

Perlu tindak lanjut dari pihak pemangku kebijakan kesehatan setempat, sejak dari tindakan pencegahan (antara lain surveilens rutin memantau jentik nyamuk dan menggalakkan Gerakan 1 Rumah 1 Jumantik), penegakan diagnosis (antara lain penyediaan kit deteksi dini infeksi Dengue), sampai penanganan pasien dengan tepat. 


\section{DAFTAR PUSTAKA}

Dinkes Jatim (Dinas Kesehatan Provinsi Jawa Timur). 2015. Profil Kesehatan Provinsi Jawa Timur Tahun 2015. Surabaya, Dinkes Jatim.

Luo L, Li X, Xiao X, Xu Y, Huang M, Yang Z. 2015. Identification of Aedes albopictus larval index thresholds in the transmission of dengue in Guangzhou, China. J Vector Ecol 40:240-246.

Pusdasure Kemenkes RI (Pusat Data dan Surveilans Epidemiologi, Kemenkes RI. 2010. Demam Berdarah Dengue. Buletin Jendela Epidemiologi Vol. 2.

Pusdatin Kemenkes RI (Pusat Data dan Informasi Kemenkes RI). 2016. Situasi Demam Berdarah Dengue di Indonesia. ISSN 2442-7659.

Pusdatin Kemenkes RI (Pusat Data dan Informasi Kemenkes RI). 2017. Data dan Informasi Profil Kesehatan Indonesia 2016.

UPTD Puskesmas Karangrejo. 2017. Laporan Tahunan UPTD Puskesmas Karangrejo Tahun 2017.

WHO, Regional Office for South East. 2011. Comprehensive and guidelines for prevention and control of dengue and dengue haemorrhagic fever. 